\title{
PELON PAIKKA
}

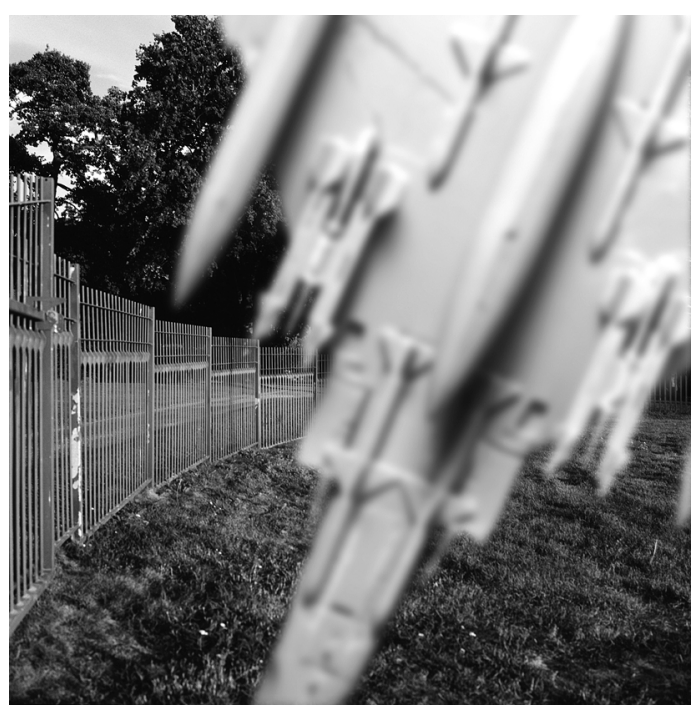

Oliver Whitehead, Fencefighter, 2004, valokuva, $120 \times 120 \mathrm{~cm}$.

Kohtalo heitti manchesteriläisen vastavalmistuneen taiteilijan Oliver Whiteheadin (s. 1947) runsas kolmekymmentä vuotta sitten Suomeen. Tuolloin hän tuskin aavisti kietoutuvansa elinikäisin sitein maahan, jonka oli tarkoitus olla vain syventävien opintojen eksoottinen kohde. Seurasi avioliitto, perhe, ura ja asteittainen integroituminen suomalaiseen taideelämään ja yhteiskuntaan.

Whitehead on kuvataiteen monitaituri, käsityöläinen, jolle melkein mikä tahansa ilmaisutapa muotokuvista performanssiin luontuu. Taiteilijana hän kuitenkin kokee olevansa yhteiskunnallisesti ja poliittisesti suuntautunut. Hänen työskentelyssään opiskeluvuosien arte povera ja käsitteellinen tarkastelutapa ovat säilyttäneet ajankohtaisuutensa ja merkityksensä.

Uusimpia teoksiaan Whitehead kutsuu "virtuaalisiksi kollaaseiksi". Ne ovat digitaalisesti käsiteltyjä valokuvia, jotka perustuvat "köyhän taiteen” etiikan ja estetiikan hengessä arkisen ympäristömme aiheisiin - jalankulkuväyliin, puistoihin ja koti-interiööreihin - ja omituisiin löydettyihin esineisiin kuten leluihin tai niiden kappaleisiin. Whitehead on taiteilija ja flanööri.

Kuvia tällaisista tiloista ja objekteista rinnastamalla ja yhdistämällä taiteilija manaa teoksissaan hienostuneesti epävarmuuden ja ahdistuksen latausta. Whiteheadin arjen estetiikka saa näin myös surrealistisia sävyjä.

Monien kohteiden valinta noudattaa "pelon maantieteen" logiikkaa. Ne ovat kuvia paikoista, joihin kaikki eivät mielellään yksin hakeudu ja joissa voi tuntea uhriksi joutumisen kammoa. Myös deformoitunut lelu itsessään tai nurin kaadettu puistonpenkki viestivät jostakin väkivaltaisesta. Latentti vaaran tunne ei sittenkään taida olla ratkaisevaa, vaan pohjimmiltaan kyse on elämän hallinnasta tai elämän hallinnan tunteesta ja sen haavoittuvaisuudesta. Kuinka vähäinenkin häiriö konventiossa tai "normaaliudessa" voi laukaista pelkomme. Outo varjostus ruokasalin kalustossa tai siveltimellä maalattu läikkä kesäisen kalliorannan idyllissä ehkä riittävät siihen.

Whiteheadin työskentelylle ominainen asiallisuus, melkeinpä realismi ja harkittu kompositio antavat poikkeamille voiman. 